\begin{tabular}{|c|c|}
\hline & Volume \& Issues Obtainable at The Women University Multan \\
Annals of Social Sciences and Perspective \\
ISSN: 2707-7063, Volume 2, No.1 June 2021
\end{tabular}

\title{
Cash Grant for Women: What we Achieved from the Income Support Program of Pakistan?
}

\author{
Mahmood Ul Hassan', Muhammad Waqas², Safana Shaheen ${ }^{3}$, Saifullah ${ }^{4}$ \\ ${ }^{1}$ Assistant Professor, Department of Economics, University of Sargodha, Pakistan. \\ ${ }^{2}$ Assistant Professor, Department of Economics, University of Sargodha, Pakistan. \\ ${ }^{3}$ Associate Professor, Higher Education Department, Punjab, Pakistan. \\ ${ }^{4}$ Lecturer, Higher Education Department, Punjab, Pakistan.
}

\begin{tabular}{lr}
\hline \multicolumn{3}{l}{ ARTICLE DETAILS } \\
\hline History: & \\
Received: & May 18, 2021 \\
Review: & June 28, 2021 \\
Accepted: & June 28, 2021 \\
Available Online: June 30,2021
\end{tabular}

\section{Keywords:}

Poverty, Benazir Income Support

Program, Women Empowermet,

Pakistan.

\begin{abstract}
The study found that Benazir Income Support Program has a positive impact to control the extent of poverty in Pakistan; however, the grant is unable to get the beneficiary out of poverty. We interviewed 1000 female beneficiaries of this social protection program from Punjab province of Pakistan and found that the amount of grants helps to manage household expenditures and their food intake has been improved. The major share of the grant goes to food followed by clothing and education. The results of multinomial regression found that an increase in the family size is the factor that blurs the poverty reduction goal of the Benazir Income Support Program. Moreover, the beneficiary belonged to the rural area and the unemployment of the household head is also the reason that the grant is unable to reduce the poverty level.
\end{abstract}

(C) 2021 The Authors, Published by WUM. This is an Open Access Article under the Creative Common Attribution Non Commercial 4.0

Corresponding author's email address: mahmoodhassan@uos.edu.pk

\section{Introduction}

The Millennium Development Goals have proven to be a powerful tool in combating poverty reduction (Awan et al, 2015). The current statistics show that most of the countries achieved the goal to control half of the poverty but on the other side the vulnerability is becoming the problem. Due to this un-sustained GDP growth, the situation of poverty and vulnerability become worse and hence the role of social protection programs becomes more important (Taylor, 2009; Jones, 2009). Shocks like natural disasters, fluctuation in commodity and input price, etc. badly hit the poor and make them more vulnerable (Krech and Bichmann, 2007; Voipio, 2007). The managed and sustained social protection system can control vulnerability and chronic poverty. Social cash transfers, according to growing research, can help poor households raise themselves out of poverty in the long run by serving as an effective risk 
management tool, promoting human capital development, and empowering poor households to lift themselves out of poverty (Scott, 2009). In addition to reducing risk and vulnerability (due to loss of income induced by external shocks), social protection can also help to decrease poverty by providing employment. Social protection programs assist people whose direct earning capability is reduced or halted due to unforeseen circumstances such as illness, accident, or disability, or old age.

The literature on social protection programs depicts that cash grant supports employment and entrepreneurial activities among the beneficiaries. The social protection program of Mexico (Progresa) significantly enhances the food expenditure of the target group, has a multiplier effect on the treatment and non-treated group of the program (Barrientos and SabatesWheeler, 2006). The self-employment and engagement of entrepreneurial activities have been boosted by social protection programs (Barber and Gertler, 2009). The social protection programs of South Africa, Brazil, Nicaragua, Honduras, and Mexico has shown that these programs successfully achieved the targets of poverty reduction, inequality removal, raised the children school enrolment, enhance the health and nutritional condition of the family, employment level, etc. (Samson et al., 2006).

Women's empowerment, participation in decision-making, and participation in incomegenerating activities are all enhanced by women-focused social protection programs (Chughtai et al., 2015; Haushofer and Shapiro, 2013; Bandiera et al., 2012). (Zaky, 2014; Khan et al., 2013). The award provides a forum for women to properly manage resources while also alleviating their financial limitations. According to the experience of social protection programs in many countries, after receiving the grant, women's participation rates in the intra-household decision making, labor market, self-employment, and resource allocation rose (Soares et al., 2010; SRC, 2008; Devereux, 2002; Bobonis et al., 2013).

In 2008, the Pakistani government acknowledged the relevance of social security programs in reducing risk and controlling chronic poverty. In Pakistan, the Benazir Income Support Program (BISP) was established to mitigate the negative effects of weak economic development, inflation, and food shortages on the poor, particularly women (Government of Pakistan, 2013-14). Women were first granted a monetary transfer of Rs. 1000 per month, which has since been increased to Rs. 1500 per month. BISP offers a shelter for the poorest of the poor, allowing them to maintain a basic level of living (Neuman, 2013). There have been few studies to assess the impact of BISP on poverty and household welfare, and everyone has their boundaries. The current study stands out for numerous reasons, including the fact that it gathered data from 1,000 recipients across Punjab province. We split Punjab province into four geographical zones and interviewed people from nineteen districts and thirty-eight tehsils to ensure that each region was properly represented. Second, we created a thorough questionnaire to assess the impact of the award on the beneficiary's poverty and household welfare. Finally, we looked at the reasons and variables that have a negative impact on the grant's poverty reduction aim.

The BISP framework in Pakistan is covered in part two of the study, and the literature on social protection and its impact on poverty and household welfare is presented in part three. Part four discusses the data sources and research methods that were used to compile this report. Part five delves into the study's findings, while the last piece gives conclusions and policy recommendations for increasing the program's efficacy. 


\subsection{Benazir Income Support Program}

In 2008, the Pakistani government, with the help of the Asian Development Bank (ADB) and the World Bank, launched a new social protection program in Pakistan to safeguard the poor and vulnerable. The ladies of such homes are the beneficiaries of the scheme, who get Rs. 1500 each month. This is a women-focused social protection program to empower women and increase their involvement in family choices. Households with a monthly income of less than Rs. 600/\$67 were chosen for the award using the Proxy Mean Test method. Furthermore, the reward should be given to female family members who are divorced, widowed, or have never married, and the candidate must have a valid National Identity Card. The grant selection procedure was broken down into two stages. In the first phase, legislators nominated the recipients of this award (2008-09 to 2010-11). To identify the poor, a proxy mean test technique was used. This method assesses the household's financial well-being on a scale of 0-100. The Nationwide Poverty Score Card Survey was launched in the second phase (2010-11) to identify the truly poor. The best method for selecting beneficiaries for social security programs that quickly and openly identify the poor is to use the Proxy Mean Test technique. In the second stage, the money was sent using a Benazir Debit Card. Beneficiaries can use this card to withdraw their grant money from an ATM. Due to its breadth, reach, and funding distribution, this programme is the largest social protection programme. In 2008, Rs. 15.8 billion was provided to this initiative, which benefited 1.8 million people. Every fiscal year, the government increases the program's funding. The government set aside Rs. 102 billion for 5.3 million beneficiaries in 2015-16.

\section{Literature Review}

The literature has been divided into two subsections that present the impact of social protection programs on poverty, household expenditure, and welfare indicators. The studies related to BISP have been discussed at the end of this section.

\subsection{Social Protection Programs and Poverty}

The social protection programs are designed to control poverty and vulnerability. Several studies investigated that poverty has been reduced for treatment groups and their consumption expenditures positively related to the amount of grant. Gertler et al. (2012) investigated that beneficiaries used the grant for further income generation activities and invested a large portion of this grant. This investment raised the long-term living standards of the treatment group and their consumption expenditures are 5.6 percent higher than the control group in Mexico. Oportunidades have long term and significant impacts on better long term living standards and poverty eradication. Acosta (2011) investigated a negative relationship between income per capita and poverty reduction. The study explored the impact of categorical and poverty targeted cash transfer in 13 Latin American countries. Using the household survey, the study focused on two programs: elderly people that are older than 65, and transfer to the children up to five years of age. Results depict that impact of transfers on poverty reduction is better in rural areas than urban. Resources are flexibly transferable in rural areas and hence achieve better results to overcome the poverty gap. The study of Paxson and Schady (2008) also found that health and cognitive development has been improved for the treated group. Moreover, the grant given to the women raised the nutrition level of the children of the treatment group. In rural Ecuador, the improvement in child health and nutrition level is substantially greater in the poorest children. Levin et al. (2009) investigated that social cash transfers remove inequality and poverty. Comparatively, Social 
Cash Transfer (SCT) has a large impact on poverty reduction than inequality. The study utilized the household income and expenditure survey of Namibia 2004. Results depict that after receiving SCT, poverty and inequality are lower as compared to the situation without SCT. Results of the probit model investigated that old age pension, and child care grant is negatively related to poverty. Skoufias and Maro (2008) explored that cash grants significantly reduce poverty in Mexico. The study examined the impact of Progresa, a cash grant program in Mexico, on adult labor participation and poverty. By interviewing 506 localities of Mexico, the study found that Progresa has no significant effect on adult labor supply choice. Moreover, no significant reduction in labor participation, after receiving a cash grant, has been seen. Duryea and Schargrodsky (2008) found that easy access to grants has a positive impact on poverty reduction. The study utilized the panel data of Jefes, conditional cash transfer (CCT) program of Argentina, and interviewed 800 beneficiaries from two cities. Results depict that beneficiaries are satisfied with payment through debit cards instead of cheques. Conversely, the less educated beneficiaries are not satisfied with the debit card facility. Moreover, payment through debit cards made the CCT program more transparent. Figari et al. (2013) evaluated the coverage and adequacy of 14 European Union countries and found that social protection programs reduced the intensity of poverty but were unable to get people out of poverty. A large number of potential people are out of the program even they fall below the poverty line. Belgium and Luxembourg are better with respect to the coverage of social protection programs than France and Germany. Portugal is the only southern European country with a comprehensive social protection scheme. Devereux (2002) concluded that social protection programs play a significant role to minimize chronic poverty. Even limited income support can generate further income generation activities and is considered as a consumption smoothing factor. Furthermore, the funding improved the target population's health and educational status. If the cash transfer is substantial enough to meet the daily consumption needs, it boosts productive investment. Behrendt (2000) found a positive impact of social security programs on poverty alleviation in Germany, Britain, and Sweden. The study utilized micro level data from the Luxembourg income study and developed thirteen model households for the computation of social assistance entitlement. Results depict those social assistance schemes of Sweden offer high benefits to beneficiaries. However, a small proportion of beneficiaries is targeted under Sweden schemes. In Germany, social assistance schemes target the exact population and hence contributing to poverty reduction.

The grant also supports better health and education of the target group. The study by Soares et al. (2010) also investigated the positive impact of 'Bolsa Familia' on poverty reduction, inequality removal, education enhancement, and employment generation. The program is playing its role positively and successfully controls poverty and inequality among beneficiaries. The education level of the families becomes better due to the grant and they can enter into the labor force. However, this program is failed to achieve its targets with respect to better health and nutrition due to supply side constraints. Schady and Arujo (2006) explored that school enrolment increased by four times when it is connected with the condition of grant in the case of Ecuador. The study evaluated the impact of Bono de Desarrollo Humano (BDH) program in Ecuador and found a positive impact of the grant on school enrollment. Parental education is strongly positively related to the enrolment rate of the children. They encouraged their children towards education. For children with a low level of parental education, their enrolment rate is 34.2 percent. De Janvry et al. (2006) also explored that conditional cash grants raised the school enrolment rate of children and reduce child labor. Progress supports the families to reduce child labor and increase the children's school enrollment rate in Mexico. Shocks badly affect the school enrollment rate of the 
children. This phenomenon is much stronger in the case of rural areas. Maluccio (2005) explored the positive impact of the safety net program on poverty alleviation in Nicaragua. Red de Protection program supported the beneficiaries to maintain their consumption expenditures after the 'Coffee Crises' in Nicaragua. Moreover, this grant substantially raised the children's school enrollment rate, decreased the child labor in the treated group, and enhanced the health condition.

Angelucci and De Giorgi (2006) found that cash grants have indirect positive impacts on nonbeneficiary consumption levels. The beneficiaries of Progresa also improve the consumption level of the non-treated household. Social protection programs not only increase the consumption level of the target group but also push the consumption expenditures of the nontarget group. The Progresa has no clear effect on labor income. Moreover, the study found that the price level does not due to the social protection grant, both for food and non-food items. Attanasio et al. (2005) found that Familias en Accion significantly increases the level of consumption expenditure, protein-rich food items, and clothes of children in Columbia. Moreover, this grant raised the enrollment rate of children of age 12-17 years. The enrolment rate of the children from 8-11 years old has been unaffected. Furthermore, the grant raised the nutrition level of the children and enhances the health condition of the treated family than the non-treated family. The situation is comparatively better for urban beneficiaries than rural beneficiaries. The study by Gertler (2004) found that beneficiaries of cash grants invest 74 percent of grants on consumption expenditures and invest the rest amount in productive assets. The study interviewed households of 506 rural communities in 7 states of Mexico and evaluated the impact of Progresa on poor rural Mexicans. Results of OLS and 2SLS explored that beneficiaries purchase agricultural inputs through which their income increases by almost 10 percent. Moreover, it is also found that cash grants are protecting poor people and also increasing productive investment in the area. Moreover, Barrientos (2003) explored that non-contributory pension income reduces poverty in Brazil and South Africa. By utilizing the household data of 2002, the study found that non-contributory pension income reduces poverty by 2.8 percentage points in South Africa and 4.2 percentage points in Brazil. Results of the probit model investigated the fact that large family sizes push households towards poverty. Moreover, public transfers reduce the probability of being poor. Imai (2003) explored that Employment Guarantee Scheme reduces poverty in rural India. By employing panel data from 1979-80 to 1984-85 of Shirapur and Kanzara states, the study observed the income pattern of eighty households. Results depict that access to borrowing, access to land, decrease in the illness of household members, and decrease in unemployment prevent household from entering into poverty. Sumarto et al. (2000) explored that safety net programs significantly protect beneficiaries from poverty shocks. The study evaluated two safety net programs: OPK (Cheap rice program in Indonesia) and Padat Karya (Labor intensive program in Indonesia). Data collection consists of 100 villages, located in 10 districts of 8 provinces of Indonesia. By interviewing 12000 households, the findings of the study concluded that the Padat Karya program is more responsive to consumption expenditure shocks than OPK. Ravallion et al. (1995) explored that cash grants protect many people from poverty but promoted few from poverty in Hungry. The study used a household budget survey of Hungry for two years, 1987 and 1989. Results of the ordinary least square (OLS) method depict that an increase in consumption poverty over the period. Moreover, the gains in social income are pro-poor. The decline in poverty is due to an increase in mean cash benefits rather than improved targeting of the poor. 


\subsection{BISP Based Studies}

In Pakistan, there is little research on BISP and its influence on poverty, family spending, and women empowerment. Some studies showed that this stipend had a beneficial influence on food spending and poverty, while others found that it has no effect. The food expenditures are positively raised by BISP while some studies found that it has no impact on poverty reduction. The major part of the grant goes to meet daily expenditures on food. This grant also supports beneficiaries towards better medical treatment. The beneficiaries can only purchase normal goods or food items from that grant. Hence, overall this grant is unable to control poverty however it supports the beneficiaries to buy the food items (Durr-e-Nayyab and Farooq, 2014; Naqvi et al. (2014)). Some studies found that this grant is achieving its goals. After obtaining BISP funding, women were more involved in household decisions. Beneficiary women make decisions about their children's education, child care, food arrangements, and other family issues (Arshad, 2011; Shehzad, 2011). Beneficiaries of the BISP also have more influence over household resources than non-beneficiaries. However, a huge number of women claimed that this grant is not sufficient to meet overall household expenditures (Shehzad, 2011).

The studies that have been done on the evaluation of BISP have their limitations like the study of Arshad (2011) collected limited data from the beneficiaries of Islamabad and only interviewed 120 beneficiaries. The study by Naqvi et al. (2014) focused on 7 union councils in Tehsil Mankera districts and attempted to determine the recipients' consumption patterns. The study by Shehzad (2011) targeted Southern Punjab and investigated the impact of BISP on beneficiary improve consumption patterns. The study by Durr-e-Nayyab and Farooq (2014) used the data of the Pakistan Panel Household Survey of 2010 and tried to explore the role of BISP towards poverty and women empowerment. The present study, through the development of the detailed questionnaire and through targeting nineteen districts of Punjab province, tried to explore the impact of BISP on poverty, household welfare and the consumption pattern of the beneficiaries.

\section{Data and Methodology}

The study is based on primary data and one thousand recipients from Pakistan's Punjab province were interviewed. The data collecting began in February 2014 and finished in October of the same year. To obtain data from the beneficiary, a multi-structured questionnaire was created. The research focuses on Pakistan's Punjab Province, which is the country's most populous province. The study classified Punjab Province into four geographical zones, according to Cheema et al. (2008): north, south, west, and central. The North area is divided into four districts, the South region into seven districts, and the West and Central regions into eight and seventeen districts, respectively. The central area of Punjab province is the biggest, with seventeen districts, followed by the west, south, and north regions. Using the probability-proportional to size sample technique, the study selected 10 districts from the central region, five districts from the west region, four and two districts from the south and north areas, respectively. A total of two tehsils were chosen at random from each district. Additionally, one rural union council and one urban union council have been chosen at random. Following the selection of union councils, twenty-five BISP recipients were questioned from a list given by the BISP district headquarters. Beneficiaries are also chosen at random. As a result, the research questioned 500 recipients from the center region, 100 from the north, and 200 each from the west and south. A total of 1,000 Punjabi beneficiaries were questioned. 
We also created an econometric model to look at the elements that influence the beneficiary's assessment of the BISP's involvement in poverty reduction. Because we had more than two categories of dependent variables, we employed the multinomial logistic regression technique. The poverty reduction variable was divided into three categories: grant decreases poverty, the grant does not reduce poverty, and grant reduces poverty to some extent. As a proxy for poverty alleviation, this variable has been employed. Area, household head's work status, and family size are all independent factors. The model's general form is as follows;

$\operatorname{logit}(y=1)=\log (p(y=1) / 1-(p-1))=\beta_{0}+\beta_{1}$ area $+\beta_{2}$ familysize $+\beta_{3}$ employment $+\mu$

\section{Results and Discussion}

The beneficiary's family information is the first section of the questionnaire. The study interviewed 50 percent of the 1000 beneficiaries from central Punjab, which comprises 17 districts, 20 percent from the south and west, and 10 percent from the north. The selection of receivers was previously discussed in the section on data and techniques. Currently, 87 percent of the recipients are married, while 9.4 percent are widows. The intriguing thing is that 1.8 percent of the recipients are also unmarried. The beneficiary's educational level is critical for the effective use and effectiveness of any social security program, however, we discovered that the majority of beneficiaries are uneducated $(95.9 \%)$, with just 4.1 percent being educated. The number of beneficiaries with only an elementary education is the greatest.

Table 1: Beneficiary Information

\begin{tabular}{|l|r|}
\hline Marital status & Percent \\
\hline Currently married & 87.1 \\
\hline Unmarried & 1.8 \\
\hline Widow & 9.4 \\
\hline Divorced & 1.5 \\
\hline Seprated & 0.2 \\
\hline Total & 100 \\
\hline Educational background & 95.9 \\
\hline Uneducated & 2.2 \\
\hline Primary & 0.5 \\
\hline Middle & 0.9 \\
\hline Matric & 0.3 \\
\hline Intermediate & 0.1 \\
\hline Bachelor & 0.1 \\
\hline Others & 100 \\
\hline Total & \\
\hline Employment status & 64.6 \\
\hline Unemployed & 35.4 \\
\hline Employed & 100 \\
\hline Total & \\
\hline Occupation & \\
\hline
\end{tabular}




\begin{tabular}{|l|r|}
\hline Daily wage worker & 35.6 \\
\hline Palour/Barber & 0.6 \\
\hline Factory worker & 0.3 \\
\hline Arming/agriculture & 0.3 \\
\hline Embriodary work & 9.9 \\
\hline Tailor & 3.1 \\
\hline Maid/Servant & 48 \\
\hline Others & 2.3 \\
\hline Total & 100 \\
\hline Monthly income of beneficiary & 4550.8 \\
\hline Mean & 1500.0 \\
\hline Minimum & 15000. \\
\hline Maximum &
\end{tabular}

More than half of the recipients are jobless, with servants and maids being the most common occupation. 35.6 percent work as daily wage workers, while 48 percent work as servants or maids. As a result, there has been a significant dispersion in the two categories of working as a housemaid and as a daily wage worker. A small percentage of the recipients also work in fields and factories (0.3 percent). Embroidery employment accounts for $9.9 \%$ of employed beneficiaries, while 3.1 percent stitch cloth at home. The beneficiary's average monthly income is 4550 rupees, with a maximum monthly income of 15000 rupees. The beneficiary's household status is highly essential and plays a key role in how the grant is used and directed to the right person. In this regard, the household head's educational level, family size, and the beneficiary's family's income level are all relevant indications. The monthly average income is Rs. 4210.10, while the monthly minimum income is Rs. 1500. The average family size of the recipient is 5.99 persons, with a maximum family size of 13 individuals. The majority of family heads are illiterate, and those who are educated attend elementary school (6.4 percent).

Table 2: Household Information of the Beneficiary

\begin{tabular}{|l|r|}
\hline Family income & Percent \\
\hline Mean & 4210.10 \\
\hline Minimum & 1500 \\
\hline Maximum & 20000 \\
\hline Family size & 5.99 \\
\hline Mean & 1 \\
\hline Minimum & 13 \\
\hline Maximum & \\
\hline Educational background of household head \\
\hline Uneducated & 89.5 \\
\hline Primary & 6.4 \\
\hline Middle & 1.2 \\
\hline Matric & 2.4 \\
\hline Intermediate & 0.2 \\
\hline Bachelor & 0.3 \\
\hline Others & - \\
\hline Total & 100 \\
\hline Employment status of the hould head \\
\hline Unemployed & 29.2 \\
\hline
\end{tabular}




\begin{tabular}{|l|r|}
\hline Employed & 70.8 \\
\hline Total & 100 \\
\hline Occupation of household head \\
\hline Daily wages worker & 61.9 \\
\hline Driver & 0.4 \\
\hline Parlor/Barber & 4.8 \\
\hline Factory worker & 0.1 \\
\hline Farming/Agriculture & 2.0 \\
\hline Embriodary work & 7.5 \\
\hline Tailor & 1.3 \\
\hline Maid/Servant & 15.3 \\
\hline Others & 6.6 \\
\hline Workshop mechanic & 0.1 \\
\hline Total & 100 \\
\hline
\end{tabular}

The majority of the beneficiaries' family heads are employed $(70.8 \%)$, with daily wage employees accounting for the most $(61.9 \%)$, followed by maid/servant employment $(15.3 \%)$, embroidery work $(7.5 \%)$, and parlor/barber work $(7.5 \%)$.

\subsection{Residential Condition}

As discussed in the introduction section that the selection of the beneficiaries is based on a multidimensional poverty approach so it is necessary to check the residential condition of the beneficiaries and to highlight the role of BISP's grant in this regard. Concerning the type of house where beneficiaries live, 61.9 percent responded that they are living in their own houses while 15.1 percent lived in rented houses and 23 percent are in another category. The other category includes different types for example; they are living without rent etc.

41.9 percent of beneficiaries are living in a house which is made of mixed material ${ }^{1}$ while 31.5 percent are living in Pakka house ${ }^{2}$ and 26.6 living in Katcha house $e^{3}$. The material of the roof is another important indicator that indicates the living condition of the household. Results depict that majority of the houses (41.9 percent) are based on the roof made of Wood/Bamboo while 21.1 percent is made of $\mathrm{RCC} / \mathrm{RBC}$ and 20.9 percent is made of Iron/cement.

Walls are the boundaries of the house and its material is also an important indicator to judge the residential condition of the beneficiary. The result shows that 47 percent of beneficiaries are living in houses where walls are made of Mud Brick/Mud, while 42 percent have walls made of Burnt Brick/block. 7.5 percent have wall material of stones and 1.8 percent build the walls made of wood/bamboo. 77.9 percent of beneficiaries are living in houses in which toilets are inside the house and vice versa for the rest of them. Along those who have the facility inside the house the flush is connected to the sewerage ( 49.7 percent) followed by flush connected with open drain (19.1 percent), and flush to the septic tank (11.6 percent).

\footnotetext{
${ }^{1}$ Some of the part of the house is made of bricks and cement and some is made of mud and other material

${ }^{2}$ House made of bricks and cement

${ }^{3}$ House made of mud, brick and other related material.
} 
Table 3: Residential Condition of the Beneficiary

\begin{tabular}{|l|r|}
\hline Type of house you live & Percent \\
\hline Own & 61.9 \\
\hline Rented & 15.1 \\
\hline Others & 23 \\
\hline Total & 100 \\
\hline \multicolumn{2}{|l|}{ Type of construction } \\
\hline Katcha & 26.6 \\
\hline Pakka & 31.5 \\
\hline Mix & 41.9 \\
\hline Total & 100 \\
\hline Material of roof & \\
\hline RCC/RBC & 21.1 \\
\hline Wood/Bamboo & 57.1 \\
\hline Iron/Cement & 20.9 \\
\hline Others & 0.9 \\
\hline Total & 100 \\
\hline Material of walls & \\
\hline Burnt brick/block & 42 \\
\hline Mud brick/mud & 47 \\
\hline Wood/bamboo & 1.8 \\
\hline Stones & 7.5 \\
\hline Others & 1.7 \\
\hline Total & 100 \\
\hline Toilet inside your home & 100 \\
\hline Yes & 22.1 \\
\hline No & 100 \\
\hline Total & 11.6 \\
\hline Kind of toilet & 19.1 \\
\hline Flush to sewerage & 8.1 \\
\hline Flush to septic tank & 10.9 \\
\hline Flush connected with open drain & \\
\hline Raised latrine & \\
\hline Pit laterine & \\
\hline Others & \\
\hline Total & \\
\hline \multicolumn{2}{|l}{} \\
\hline
\end{tabular}

The interesting thing is that large proportion (77.6 percent) of the beneficiaries has mobile phone while 1.1 percent have landline phone only. Out of total beneficiaries, 21.1 percent of beneficiaries have no working telephone. This figure is behaving contradictory trend with the ground realities that 21 percent of beneficiaries have no way to contact with others. The majority of the beneficiaries are using firewood (69.2 percent) as a fuel for cooking while some of them are using gas (19.2 percent), and crop residue (9.9 percent). More than half of the beneficiaries used hand pump water (51.4 percent) followed by motorized pump (7.5 percent) and piped into the house (5.3 percent). 
Table 4: Facilities

\begin{tabular}{|l|r|}
\hline Working telephone & Percent \\
\hline No & 21.1 \\
\hline Landline only & 1.1 \\
\hline Mobile only & 77.6 \\
\hline Landline and mobile & 0.2 \\
\hline Total & 100 \\
\hline Fuel for cooking & 69.2 \\
\hline Firewood & 19.2 \\
\hline Gas & 0.8 \\
\hline Kerosene oil & 0.7 \\
\hline Electricity & 9.9 \\
\hline Crop residue & 0.2 \\
\hline Charcoal/coal & 100 \\
\hline Total & \\
\hline Type of clean water & 4.7 \\
\hline Tap & 5.3 \\
\hline Piped into house/compound & 29 \\
\hline Outdoor tap & 51.4 \\
\hline Hand pump & 7.5 \\
\hline Motorized pump & 0.6 \\
\hline Protected well & 0.2 \\
\hline River/lake/pound & 0.9 \\
\hline Tanker/truck vendor & 0.4 \\
\hline Others & 100 \\
\hline Total &
\end{tabular}

\subsection{BISP Grant and Impact on Food}

One of the prime objectives behind the initiative of BISP is to remove poverty and vulnerability. Several studies related to BISP found that it only helps to address the necessities and daily household expenditures (Durr-e-Nayyab and Farooq, 2014; Naqvi et al., 2014; Shehzad, 2011; USAID, 2011). More than half of the beneficiaries (58 percent) responded that this grant addresses their basic needs and major share goes to food $(80.2$ percent) followed by clothing (15.5 percent), others (3.1 percent), and shelter (1.2 percent). The majority of the beneficiaries (41.9 percent) replied that this grant is unable to address the basic needs. They responded that it does not address clothing (31.3 percent) and shelter (18.5) as major components.

Table 5: BISP Grant and Impact on Food

\begin{tabular}{|l|r|}
\hline $\begin{array}{l}\text { Has cash transfer addressed your basic } \\
\text { needs }\end{array}$ & Percent \\
\hline Yes & 58.1 \\
\hline No & 41.9 \\
\hline Total & 100 \\
\hline If yes, what has it addressed \\
\hline
\end{tabular}




\begin{tabular}{|l|r|}
\hline Food & 80.2 \\
\hline Clothing & 15.5 \\
\hline Shelter & 1.2 \\
\hline Others & 3.1 \\
\hline Total & 100 \\
\hline If no, what has it not addressed & 14.5 \\
\hline Food & 31.3 \\
\hline Clothing & 18.5 \\
\hline Shelter & 35.8 \\
\hline Others & 100 \\
\hline Total & \\
\hline Give Options, which alternative to cash transfer would \\
you prefer & 19.2 \\
\hline Food voucher & 8.6 \\
\hline Food for work & 49.5 \\
\hline Business grants & 22.7 \\
\hline Others & 100 \\
\hline Total &
\end{tabular}

The question was also asked for beneficiaries to give option about the alternative of a cash grant, 49.5 percent were in favor of giving business grants followed by food vouchers $(19.2$ percent) and food for work (8.6 percent).

\subsection{Household Welfare and Poverty}

The third major objective is to reduce the poverty and enhance household welfare. Currently, 5.3 million beneficiaries are getting benefits from this program. The 40.3 percent of beneficiaries responded that BISP helps them to get out of poverty while few beneficiaries (12.6 percent) responded that it fails to reduce poverty. Almost half of the beneficiaries (47.1 percent) replied that sometimes they can control poverty and this grant helps them to maintain their budget. The almost same trend has been observed regarding household expenditure, 39.5 percent of beneficiaries responded that this grant helps them to manage household expenditure, 16.6 percent replied that this amount is unable to assist them to manage expenditures. Several studies in the literature found that social protection programs are successful to reduce the poverty level. The grant gives support to manage the household expenditures (Gertler et al., 2012; Skoufias and Maro, 2008; Soares et al., 2010; Malvccio, 2005; Barrientos, 2003; Behrendt, 2000).

Table 6: Impact of BISP on Poverty

\begin{tabular}{|l|r|}
\hline $\begin{array}{l}\text { Do you think this amount helps to reduce } \\
\text { your household poverty }\end{array}$ & Percent \\
\hline Yes & 40.3 \\
\hline No & 12.6 \\
\hline Sometimes & 47.1 \\
\hline Total & 100 \\
\hline $\begin{array}{l}\text { Does the amount assist you manage the household } \\
\text { expenditure }\end{array}$ \\
\hline Yes & 39.5 \\
\hline
\end{tabular}




\begin{tabular}{|l|r|}
\hline No & 16.6 \\
\hline Sometimes & 43.9 \\
\hline Total & 100 \\
\hline $\begin{array}{l}\text { Since grant disbursement, has the food intake in the } \\
\text { household }\end{array}$ \\
\hline Improved & 64.7 \\
\hline Stayed same & 31 \\
\hline Worsend & 4.3 \\
\hline Total & 100 \\
\hline $\begin{array}{l}\text { Among households with food stores, length of time } \\
\text { stores will last }\end{array}$ \\
\hline Less than 1 week & 32 \\
\hline 1-4 week & 64 \\
\hline 1-2 months & 3 \\
\hline 3-6 months & 100 \\
\hline Total & \\
\hline
\end{tabular}

The grant has a positive impact on the dietary condition of the family of the beneficiary because 64.7 percent responded that since grant disbursement there is improvement in the food intake, 31 percent replied that it stays the same while 4.3 percent responded that it becomes worse. The majority of the beneficiaries $(87.6$ percent) replied that the grant is unable to support us to build an asset. Social protection programs are unable to build assets because the major focus of these grants is to support the poor to get out of poverty and to manage household expenditures. The major share goes to food items, health and education expenditures (Barber and Gertler, 2009; Schady and Resero, 2007; Attanasio et al., 2005).

One of the most important questions is about the economic situation since the grant was received. Almost half of the beneficiaries responded that their economic situation is better since they are receiving a grant from BISP, only 14. Percent responded that it becomes worse, while 40.8 percent replied that their economic situation remains the same. Social protection programs not only help to reduce poverty and inequality but also protect the poor from poverty shocks (Figari et al., 2011; Sumarto et al., 2000).

Table 7: Impact of BISP on Welfare

\begin{tabular}{|l|r|}
\hline Does the amount helps to build assets & Percent \\
\hline Yes & 2.7 \\
\hline No & 87.6 \\
\hline Sometimes & 9.7 \\
\hline Total & 100 \\
\hline Economic situation since grant received \\
\hline Better & 45.1 \\
\hline Worse & 14.1 \\
\hline Same & 40.8 \\
\hline Total & 100 \\
\hline
\end{tabular}




\section{Econometric Analysis}

Results of multinomial logistics regression depict that beneficiaries from the urban area are 6 times more likely to be in a group whose poverty level decreases than those who claim that grant is failed to reduce poverty level. With the increase in the family size, the beneficiary is 21 percent less likely to be in a group that claims that amount of grant reduces poverty than the group that claims that it failed to reduce poverty. A beneficiary whose household head is employed is 1 time more likely to be in a group whose poverty level decreases than those who claim that grant is failed to reduce poverty level. Beneficiaries from rural area are 15 times less likely to be in a group whose response is that amount of grant to some extent reduces poverty than those who claims that grant is failed to reduce poverty level. With the increase in the family size, the beneficiary is 15 percent less likely to be in a group that claims that amount of grant to some extent reduces poverty than those who claim that it failed to reduce poverty. A beneficiary whose household head is employed is 1 time more likely to be in a group whose response is that amount of grant to some extent reduce poverty level than those who claims that grant is failed to reduce poverty level.

Table 8: Results of Multinomial Logistic Regression

\begin{tabular}{|c|c|c|c|c|c|c|}
\hline \multirow{2}{*}{$\begin{array}{c}\text { Women } \\
\text { empowerment }\end{array}$} & \multirow{2}{*}{ Variables } & \multirow{2}{*}{ B } & \multirow{2}{*}{ Sig. } & \multirow{2}{*}{$\operatorname{Exp}(B)$} & \multicolumn{2}{|c|}{$\begin{array}{c}95 \% \text { confidence } \\
\text { interval for } \operatorname{Exp}(B)\end{array}$} \\
\hline & & & & & $\begin{array}{l}\text { Lower } \\
\text { bound }\end{array}$ & $\begin{array}{l}\text { Upper } \\
\text { bound }\end{array}$ \\
\hline \multirow{8}{*}{$\begin{array}{l}\text { Amount of } \\
\text { grant reduces } \\
\text { poverty }\end{array}$} & Intercept & 1.532 & 0.001 & & & \\
\hline & $\begin{array}{l}\text { Area } \\
\text { Urban=0 } \\
\text { Rural=1 }\end{array}$ & 0.098 & 0.030 & 1.103 & 0.629 & 1.934 \\
\hline & Family size & -0.229 & 0.001 & 0.796 & 0.698 & 0.907 \\
\hline & $\begin{array}{l}\text { Employment } \\
\text { status } \\
\text { Unemployed=0 } \\
\text { Employed=1 }\end{array}$ & 0.608 & 0.034 & 1.836 & 1.047 & 3.219 \\
\hline & $\begin{array}{l}\text { Intercept } \\
\text { Area }\end{array}$ & 1.615 & 0.000 & & & \\
\hline & Urban $=0$ & -0.154 & 0.580 & 0.858 & 0.498 & 1.476 \\
\hline & $\begin{array}{l}\text { Rural=1 } \\
\text { Family size }\end{array}$ & -0.161 & & & & \\
\hline & $\begin{array}{l}\text { Employment } \\
\text { status } \\
\text { Unemployed=0 } \\
\text { Employed=1 }\end{array}$ & 0.059 & 0.836 & 1.060 & 0.609 & 1.847 \\
\hline $\begin{array}{l}\text { Pseudo R- } \\
\text { Square } \\
\text { Nagelkerke }\end{array}$ & 0.065 & \multicolumn{4}{|c|}{$\begin{array}{l}\text {-2 Log Likelihood of Reduced Model } \\
\text { Intercept } \\
\text { Area } \\
\text { Family size } \\
\text { Employment status }\end{array}$} & $\begin{array}{c}2.304 \\
231.540 \\
242.899 \\
237.283\end{array}$ \\
\hline
\end{tabular}




\section{Conclusion and Policy Implications}

The multidimensional impacts of social protection on the treated group made this strategy a powerful tool to eradicate poverty and vulnerability and to raise the welfare status of the beneficiary. The success of these programs depends on the accurate and transparent selection of beneficiaries (De Janvry et al., 2006), coverage, sustainability, and range of the program. The successful programs of several countries like Mexico's 'Progresa', Bangladesh's 'Targeting Ultra Poor', Uganda's 'Social Assistance Grants for Empowerment', Brazil's 'Bolsa Familia', Ecuador's 'Bono de Desarrollo Humano' adopted transparent and efficient strategies. In 2008, the Government of Pakistan started Benazir Income Support Program to control poverty and vulnerability. Due to its coverage, range, reach and funding this is the largest social protection program in Pakistan.

The present study interviewed 1000 beneficiaries of the Punjab province of Pakistan and investigated the impact of this grant on poverty and household welfare. The results of the study supported that the grant helps to control the extent of poverty in Pakistan. This grant helps to manage household expenditures and their food intake has been improved. Moreover, the economic situation of the household is better after the grant. The major share of the grant goes to food followed by clothing and education. However, the grant is unable to get the beneficiary out of poverty. One possible reason might be the inflation in the country. The increase in the number of grants is not proportional to the increase in the inflation rate in the country. To investigate the factors that affect the poverty reduction goals of this grant, we developed an econometric model. The results of the multinomial regression method explored that family size is the factor that negatively affects the poverty reduction goal of the Benazir Income Support Program. Furthermore, the beneficiary belonged to the rural area and the unemployment of the household head are also the reasons that the grant is unable to reduce the poverty level. Based on the findings, we suggest that there is a need to increase the range of this program so that the maximum number of poor can get benefits from this program. Furthermore, conducting a yearly third-party impact review will aid in the investigation of the program's loopholes and weaknesses in operation.

\section{References}

Acosta, P., Leite, P., and Riglini, J. (2011). Should Cash Transfers Be Confined to the Poor? Implications for Poverty and Inequality in Latin America. IZA Policy Paper No. 34

Angelucci, M. and De Giorgi, G. (2009). Indirect Effects of an Aid Program: How Do Cash Transfers Affect Ineligibles' Consumption?. American Economic Review, 99(1): 486-508.

Arshad, M. (2011). Does Money Matter for Women's Empowerment? A Study of the Benazir Income Support Program (BISP) Pakistan. Population Poverty and Social Development (PPSD).

Attanasio O., Gomez L.C., Heredia P., and Vera-Hernandez M. (2005). The short-term impact of a conditional cash subsidy on child health and nutrition in Colombia. London: Institute of Fiscal Studies; 2005.

Awam, M.S., Waqas, M., Aslam, M. A. (2015). Multidimensional measurement of poverty in Pakistan: provincial analysis. Noesis, 24(48): 56-71.

Bandiera, O., Buehren, N., Burgess, R., Goldstein, M., Gulesci, S., Rasul, I., and Sulaiman, M. (2012). Empowering Adolescent Girls: Evidence from a Randomized Control Trial in Uganda. Washington, DC : World Bank Group. 
Barber, S. L., and Gertler, P. J. (2009). Empowering women to obtain high quality care: evidence from an evaluation of Mexico's conditional cash transfer programme. Health Policy and Planning, 24(1), 18-25.

Barrientos, A. and Sabates-Wheeler, R. (2006). Local Economy Effects of Social Transfer -Final Report for DFID, Institute of Development Studies (IDS), University of Sussex, Brighton.

Barrientos, A. (2003). What is the impact of non-contributory pensions on poverty? Estimates from Brazil and South Africa. CPRC Working Paper No 33.

Behrendt, C. (2000). Do means-tested benefits alleviate poverty?: Evidence on Germany, Sweden and the United Kingdom from the Luxembourg Income Study. Journal of European Social Policy,10(1), 23-41.

Bobonis, G. J., González-Brenes, M., and Castro, R. (2013). Public Transfers and Domestic Violence: The Roles of Private Information and Spousal Control. American Economic Journal: Economic Policy, 5(1): 179-205.

Cheema, A., Khalid, L., and Patnam, M. (2008). The Geography of Poverty: Evidence from the Punjab. The Lahore Journal of Economics, Special Edition: 163-188.

Chughtai, M. W., Zaheer, M. F., Taj, S. (2015). Estimating the Effects of Microcredit on Women's Empowerment: An Empirical Evidence from District Attock. Research journal of social sciences and management, 4(11): 167-176.

De Janvry, A., Sadoulet, P., Solomon, A., and Vakis, R. (2006). Uninsured Risk and Asset Protection: Can Conditional Cash Transfer Programs Serve as Safety Nets? Social Protection Discussion Paper 0604, The World Bank, Washington DC.

Devereux, S. (2002). Social Protection for the Poor: Lessons from Recent International Experience, Institute of Development Studies (IDS) Working Paper 142, IDS, University of Sussex, Brighton.

Durr-e-Nayyab and Farooq, S. (2014). Effectiveness of Cash Transfer Programmes for Household Welfare in Pakistan: The case of the Benazir Income Support Programme. The Pakistan Development Review, 53(1):75-104.

Duryea, S. and Schargrodsky, E. (2008). Financial Services for the Poor: Welfare, Savings and

Consumption. http://siteresources.worldbank.org/INTFR/Resources/DuryeaSchargrodsky150208.pdf

Figari, F., Matsaganis, M., and Sutherland, H. (2013). Are European social safety nets tight enough? Coverage and adequacy of minimum income schemes in 14 EU countries. International Journal of Social Welfare, 22: 3-14.

Gertler, P, Martinez, S. and Rubio-Codina, M. (2012). Investing Cash Transfers to Raise Long-Term Living Standards. American Economic Journal, Applied Economics, 4 (1): 164-92.

Gertler, P. (2004). Do Conditional Cash Transfers Improve Child Health? Evidence from Progresa's Control Randomized Experiment. American Economic Review, 94(2), 332-341.

Government of Pakistan. Pakistan Economics Survey 2013-14, Finance Division, Planning Commission of Pakistan.

Haushofer, J., and Shapiro, J. (2013). Welfare Effects of Unconditional Cash Transfers: Evidence. from a Randomized Controlled Trial in Kenya. Working paper. From https://www.princeton.edu/ joha/publications/Haushofer_Shapiro_Policy_Brief_2013 . $\mathrm{pdf}$

Imai, K. (2003) The Employment Guarantee Scheme as a Social safety Net-Poverty Dynamics and Poverty Alleviation. Department of Economics \& St. Antony's College, University of Oxford Discussion Paper Series. 
Jones, H. (2009). Equity in development: Why it is important and how to achieve it. Working Paper 311. Overseas Development Institute, London

Khan, T. H., Islam, Md., Ershadul., Talukder, Md. Ishtiaq, A., Khan, Md. Bashir Uddin (2013). Micro Credit-Women Empowerment Nexus Explored: A Study on the Women of Selected Rural Areas in Natore District, Bangladesh. Research on humanities and social sciences, 3(3): 110-120.

Krech, R. and Bichmann, R. (2007). Social protection in German Development Cooperationl, entwicklung \& ländlicher raum 3/2007.

Levine, S., Van Der Berg, S. and Yu, D. (2009). Measuring the Impact of Social Cash Transfers on Poverty and Inequality in Namibia, Stellenbosch Economic Working Papers: 25/09.

Maluccio, J. A. (2005). Coping with the 'Coffee Crisis' in Central America:The role of the Nicaraguan Red de Protección Social. IFPRI Discussion Paper 188, Food Consumption and Nutrition Division. Washington, DC: International Food Policy Research Institute

Naqvi, S. M., Muddassir, A., Sabir, H. M., Shamim, A., Tariq, M. (2014). Social Safety Nets and Poverty in Pakistan (A Case Study of BISP in Tehsil Mankera District Bhakkar). Journal of Finance and Economics, 20142 (2): 44-49.

Newman, J. (2013). Recovering strong positive trends in poverty and opportunity (Pakistan Policy Note 5). Washington, DC: World Bank.

Paxson, C. and Schady, N. (2008). Does money matter? The effects of cash transfers on child health and development in rural Ecuador. Unpublished manuscript, Washington, DC: World Bank

Ravallion, M., Van de Walle, D., Gautam, M. (1995). Testing a social safety net. Journal of Public Economics, 57: 175-199.

Samson, M., MacQuene, K. and Van Niekerk, I. (2006). Designing and Implementing Social Transfer Programmes, EPRI, Cape Town.

Schady, N. and Rosero, J. (2007). Are Cash Transfers Made to Women Spent Like Other Sources of Income? World Bank Policy Research Working Paper 4282.

Schady, N., and Araujo, M.C. (2006). Cash transfers, conditions, school enrollment, and child work: evidence from a randomized experiment in Ecuador. Policy Research Working Paper Series 3930. Washington DC: The World Bank.

Scott, J. (2009). Social Transfers and Growth in Poor Countries, Promoting pro-poor growth: social protection, OECD.

Shehzad, I. (2011). Benazir Income Support Programme (BISP) and its Impact on Women's Empowerment. SAARC Journal of Human Resource Development

Skoufias, E. and Maro, Vincenzo Di (2008). Conditional Cash Transfers, Adult Work Incentives, and Poverty. The Journal of Development Studies, 44(7): 935-960.

Soares, F. V., Ribas, R. P., and Osório, R. G. (2010). Evaluating the Impact of Brazil's Bolsa Família: Cash Transfer Programmes in Comparative Perspective. Latin American Research Review, 45(2): 173-190.

SRC (Social Research Centre). (2008). Introducing Empowering Conditional Cash Transfers to Egypt: The Ain el-Sira Experiment", 30-31 January, SRC, American University in Cairo (2008).

Sumarto, S., Asep, S., and Pritchett, L. (2000). Safety Nets and Safety Ropes:Comparing the Dynamic Benefit Incidence of Two Indonesian "JPS" Programs. Jakarta:Social Monitoring and Early Response Unit.

Taylor, L. (2009). Growth, Development Policy, Job Creation and Poverty Reduction. DESA Working Paper No. 90. ST/ESA/2009/DWP/90 
Voipio, T. (2007). Social Protection for Poverty Reduction: The OECD/DAC/POVNET Viewll, Institute of Development Studies (IDS) Bulletin, IDS, University of Sussex, Brighton.

World Bank (2011). Empowering Women through BISP: The Effect of Women's Decision-Making Power on Reproductive Health Services Uptake in Pakistan. Social Protection South Asia Human Development The World Bank Group

Waqas, M., and Torre, A. (2020). Political favouritism and social conflict: a case study of the Benazir Income Support Programme (BISP) in Pakistan. Area Development and Policy, 5:3, pp. 334-349.

Waqas, M., and Awan, M. S. (2019). Do Cash Transfers Effect Women Empowerment? Evidence from Benazir Income Support Program of Pakistan. Women's Studies, 48:7, 777-792.

Waqas, M., and Awan, M. S. (2018). Access to better health? The Impact of the Benazir Income Support Programme in Pakistan. Asia Pacific Journal of Public Administration, Vol. 40, No. 1, pp. 74-81.

Waqas, M., and Awan, M. S. (2017). Social Protection, Gender, and Poverty: Application of Social Protection Index. Journal of Policy Practice, Vol. 16, No. 4, pp. 369-380.

Zaky, H. (2014). Does the conditional cash transfer program empower women? Evidence from Ain El-Sira, Egypt. Social Sciences, 3: 132-136. 